\title{
丁二酸酐修饰对漆酶稳定性和除酚效率的影响
}

\author{
熊亚红，高敬忠，郑坚鹏，邓乃康 \\ 华南农业大学理学院生物材料研究所, 广东广州 510640
}

\begin{abstract}
摘要: 采用 $\left(\mathrm{NH}_{4}\right)_{2} \mathrm{SO}_{4}$ 分步沉淀法对诺维信中国公司生产的漆酶制剂 DeniLite IIS 进行了纯化, 并用丁二酸酐 (SA) 对纯化酶 进行了化学修饰, 运用三硝基苯磺酸法、紫外光谱法及苂光光谱法对修饰效果进行了初步表征, 比较了天然酶和修饰酶的 $\mathrm{pH}$ 稳定性、热稳定性及除酚效率. 结果表明, 修饰酶的平均氨基修饰度为 $85 \%$, 其紫外吸收峰和荧光发射峰均出现蓝移, 而且紫外 吸收减小、荧光强度增加. 尽管采用 SA 化学修饰未能改变漆酶的最适反应温度, 但使其最适反应 $\mathrm{pH}$ 值由 4.5 提高到 5.5 , 并 且使酶活提高 $60 \%$. 与天然酶相比, 修饰酶的 $\mathrm{pH}$ 稳定性和热稳定性更高, 催化效率 $\left(k_{\mathrm{cat}}\right)$ 和酶与底物的亲和力 $\left(k_{\mathrm{cat}} / K_{\mathrm{m}}\right)$ 分别提 高了 $53 \%$ 和 $122 \%$, 对邻、间和对苯二酚的除酚效率分别提高了 $48 \%, 57 \%$ 和 $18 \%$. 这预示着这些修饰漆酶可望应用于工业生 产和酚类污染废水的治理.
\end{abstract}

关键词: 丁二酸酐; 漆酶; 化学修饰; 稳定性; 动力学; 除酚效率

中图分类号: O643 文献标识码: A

收稿日期: 2011-05-16. 接受日期: 2011-07-18.

*通讯联系人. 电话: (020)85280323; 传真: (020)85285026; 电子信箱: xiongyahong@scau.edu.cn

基金来源：华南农业大学“211 工程”三期重点学科建设项目 (2009B010100001); 国家自然科学基金 (20906034B0604); 国家林 业局项目 (2011-4-75).

本文的英文电子版(国际版)由Elsevier出版社在ScienceDirect上出版(http://www.sciencedirect.com/science/journal/18722067).

\section{Effects of Succinic Anhydride Modification on Laccase Stability and Phenolics Removal Efficiency}

\author{
XIONG Yahong ${ }^{*}$, GAO Jingzhong, ZHENG Jianpeng, DENG Naikang \\ Institute of Biomaterial, College of Science, South China Agricultural University, Guangzhou 510642, Guangdong, China
}

\begin{abstract}
Chemical modification is a useful method to change the properties of enzymes. Laccase is a phenol oxidase belonging to a multicopper protein, which catalyzes the oxidation of many phenolics. DeniLite IIS, a commercial laccase preparation from the Novozymes China Company, was purified by ammonium sulfate fractional precipitation. Succinic anhydride (SA) was used as a modifier for the chemical modification of the purified laccase. The effects of modification were characterized using the 6-trinitrobenzene sulfonic acid method, ultraviolet spectroscopy, and fluorescence spectroscopy. The $\mathrm{pH}$ stability, thermal stability, and the phenolics removal efficiency for the native and modified laccases were compared. The results showed that the average amino modification yield of the modified laccase was $85 \%$ and the modified laccase had a blue shifted ultraviolet peak and fluorescence emission peak as well as a decrease in the ultraviolet absorbance and an increase in the fluorescence intensity. Although chemical modification with SA did not change the optimum temperature for the catalysis of the laccase, it caused the optimum $\mathrm{pH}$ of the catalysts to shift from 4.5 to 5.5 and the enzymatic activity increased by $60 \%$. Compared with the native laccase, the modified laccase exhibited remarkably higher $\mathrm{pH}$ stability and thermal stability and its catalysis efficiency $\left(k_{\text {cat }}\right)$ and substrate affinity $\left(k_{\mathrm{cat}} / K_{\mathrm{m}}\right)$ increased by $53 \%$ and $122 \%$, respectively. The phenolics removal efficiency (o-, $m-$, $p$-dihydroxybenzene) of the modified laccase increased by $48 \%, 57 \%$, and $18 \%$, respectively. These results indicate that the modified laccase with higher stability and higher efficiency is suitable for application in industrial production and for the treatment of phenolics-polluted water.
\end{abstract}

Key words: succinic anhydride; laccase; chemical modification; stability; kinetics; phenolics removal efficiency 
This work was supported by the key Academic Program of the 3rd Phase "211 Project" of South China Agricultural University (2009B010100001), the National Natural Science Foundation of China (20906034B0604), and the State Bureau of Forestry Project (2011-4-75).

English edition available online at Elsevier ScienceDirect (http://www.sciencedirect.com/science/journal/18722067).

Laccases (Lac, EC 1.10.3.2) belong to a group of polyphenol oxidases containing copper atoms in the catalytic centre and they are usually referred to as multicopper oxidases [1]. It was first found in the exudates of the Japanese lacquer tree and a few years in fungi and bacteria. Laccases from different sources have different molecular weights and oxidation capacities [2]. There are four copper atoms in the active centre of laccase. According to their spectroscopic properties these four copper atoms are divided into three types, types I, II, and III. Type I copper plays an important role in the oxidation capacity of laccase [3]. Laccase has a wide range of substrate specificity and it can use oxygen directly as an oxidant to catalyze substrate oxidation. The four copper atoms in laccase transport electrons synergistically during catalysis [4].

Many reports have shown that laccase is an interesting prospect for application in detoxification, decolorization, and biological examinations [2]. It is destined to become an industrially-relevant enzyme. Phenolics are major organic pollutants in water environments and most phenolics are toxic to living organisms. Since laccase can use various types of aromatics such as phenolics as substrates, many studies have been carried out on phenolic wastewater treatment by laccase [5].

In general, low stability and the potential for a drastic reduction in enzymatic activity have always been considered a hindrance to the practical application of enzymatic systems. Laccase as a biocatalyst also has these shortcomings [6]. Therefore, the enhancement of laccase stability is important and urgent. Many methods have been used to modify the properties of enzymes such as genetic engineering including site-directed mutagenesis and molecular evolution, chemical modification including monofunctional polymer substitution and small molecule modification, and cofactor introduction [7-9]. Chemical modification leads to the introduction of functional groups and specificity-determining groups that are inaccessible by conventional mutagenesis techniques and improvements in enzyme activity and/or stability are achieved at low cost using relatively straightforward methods $[8,10]$. Therefore, chemical modification is an alternative (and complementary) approach to genetic modification for modifying their activity-stability properties. Recently, some attempts have been made to enhance laccase stability and efficacy by chemical modification. The chemical reagents used include polyethylene glycol (PEG) [11,12], dextran [13], citraconic anhydride (CA) [14], ethyl-
ene-glycol-N-hydroxy succinimide (EGNHS) [15], glutaraldehyde [14], and polyalkyleneoxide-co-maleic anhydride [6], and they were used as modifiers of fungal laccases. As the structure and function of laccase is now understood more clearly, it is known that lysine residues are not a part of the active site of laccase [2,4]. Because of its strong electrophilicity, the $\varepsilon-\mathrm{NH}_{2}$ of lysine can react with many electrophiles. Therefore, laccase can be chemically modified by dicarboxylic anhydrides. Our earlier studies on horseradish peroxidase [15], porcine pancreas lipase (PPL) [16], and papain [17] modified with PA have shown that the stability and the efficacy of the modified enzyme increased.

The commercial laccase preparation, DeniLite IIS, which is produced by Novozymes is the laccase from $M y$ celiophthora thermophila expressed genetically in Aspergillus oryzae. Although DeniLite IIS is in great demand, it is necessary to enhance the stability and efficacy of laccase as the core composition of this preparation. In this paper, the laccase in DeniLite IIS was purified and the purified laccase was chemically modified by succinic anhydride (SA). The modified laccase was characterized by average amino modification yield detection, ultraviolet spectroscopy, fluorescence spectroscopy, $\mathrm{pH}$ stability, thermal stability, and the removal efficiency of phenolics. This work will be beneficial to promote the practical application of laccase.

\section{Experimental}

\subsection{Chemicals}

Crude laccase (120 LAMU/g) designated DeniLite IIS was kindly provided by the Novozymes China company (Tianjin). Bovine serum albumin (BSA), (2,2'-azino-bis (3-ethylben-zothiazoline-6-sulfonic acid) diammonium salt (ABTS), tris(hydroxymethyl) aminomethane (Tris), acrylamide, $N, N$ '-methylenebis(acrylamide), sodium dodecylsulfate (SDS), $\quad N, N, N^{\prime}, N^{\prime}$-tetramethylethylenediamine (TEMED), and ammonium persulfate were obtained from Sigma (St. Louis, Missouri, USA). All other chemicals such as SA, $o-, m-, p$-dihydroxybenzene (o-, $m-, p$-DHB) et al., were analytical reagents from China. The water used was double-distilled.

\subsection{Laccase activity assay}

The activity of laccase was determined spectrophotomet- 
rically using ABTS as a substrate. The detailed method was improved according to Bourbonnais and Paice [18]. The reaction mixture contained $1.0 \mathrm{ml} 0.50 \mathrm{mmol} / \mathrm{L}$ ABTS, 1.5 $\mathrm{ml} 0.10 \mathrm{~mol} / \mathrm{L}$ acetate buffer $(\mathrm{pH}=4.5)$, and $0.5 \mathrm{ml}$ the appropriately diluted enzyme solution. After incubation at $25^{\circ} \mathrm{C}$ for $3 \mathrm{~min}$, the increase in absorbance was monitored at $420 \mathrm{~nm}$. The molar extinction coefficient $\varepsilon$ was 36000 $\mathrm{L} /(\mathrm{mol} \cdot \mathrm{cm})$. One unit of enzyme activity was defined as 1 $\mu \mathrm{mol}$ of ABTS oxidized per minute at $25^{\circ} \mathrm{C}$. Analysis was carried out in duplicate. The data given here are average values.

\subsection{Purification of crude laccase and electrophoresis}

Crude laccase was dissolved in $0.10 \mathrm{~mol} / \mathrm{L}$ acetate buffer at $\mathrm{pH}=4.5$ and precipitated fractionally with ammonium sulfate at $4{ }^{\circ} \mathrm{C}$. The $45 \%-80 \%$ ammonium sulfate cut-off fraction was dissolved in $0.010 \mathrm{~mol} / \mathrm{L}$ acetate buffer at $\mathrm{pH}=$ 4.5 and it was then dialyzed in the same acetate buffer overnight and lyophilized at $-50^{\circ} \mathrm{C}$.

Sodium dodecylsulfate-polyacrylamide gel electrophoresis (SDS-PAGE) was performed on a Bio-RAD MINI-PROTEAN II, as described by Laemmli [19] in a $12 \%(\mathrm{~m} / \mathrm{v})$ polyacrylamide slab gel. Protein bands were visualized by staining with Coomassie Brilliant Blue R-250.

The protein concentration was estimated, as described by Lowry et al. [20] using BSA as a standard.

\subsection{Chemical modification of the crude laccase}

The chemical modification of laccase with SA was performed according to our previously described method [15-17,21]. The native laccase lyophilized powder was dissolved in $0.025 \mathrm{~mol} / \mathrm{L}$ phosphate buffer at $\mathrm{pH}=7.5$ to yield a $1 \mathrm{mg} / \mathrm{ml}$ enzyme solution. SA was dissolved in 0.025 $\mathrm{mol} / \mathrm{L}$ phosphate buffer at $\mathrm{pH}=7.5$ with $4 \%(v / v)$ dimethylsulfoxide to prepare a $2 \mathrm{mmol} / \mathrm{L}$ SA solution. The SA solution $(10.0 \mathrm{ml})$ was added gradually with constant stirring to $10.0 \mathrm{ml}$ of the laccase solution. The reaction was proceeded for $1 \mathrm{~h}$ at $4{ }^{\circ} \mathrm{C}$ and the solution was dialyzed against $0.010 \mathrm{~mol} / \mathrm{L}$ acetate buffer at $\mathrm{pH}=4.5$ overnight at $4^{\circ} \mathrm{C}$ to remove excess reagents and then lyophilized.

\subsection{Degree of modification}

The degree of modification (DM) is expressed by the average amino modification yield, which was determined by the 6-trinitrobenzenesulfonate (TNBS) method [22]. A solution without enzyme protein was used as a reference. The measurement of the TNBS reaction mixture absorbance was carried out using a UV-4000 spectrophotometer (HITACHI, Japan). The DM was calculated by the following equation:

$$
\mathrm{DM}=\left(\Delta A_{\mathrm{Lac}}-\Delta A_{\mathrm{SA}-\mathrm{Lac}}\right) \times 100 \%
$$

where $\Delta A_{\mathrm{Lac}}$ and $\Delta A_{\mathrm{SA} \text {-Lac }}$ represent the absorbance at 420 $\mathrm{nm}$ for the native and the SA-modified laccases, respectively, at the same enzyme molar concentration.

\subsection{Spectral analysis}

UV-Vis spectra of the native and modified laccase at the same molar concentration were recorded at $25{ }^{\circ} \mathrm{C}$ with a UV-4000 spectrophotometer. Fluorescence spectra using $272 \mathrm{~nm}$ as the excitation wavelength were measured at 25 ${ }^{\circ} \mathrm{C}$ with a F-4500 spectrofluorometer (HITACHI, Japan).

\subsection{Determination of optimum $\mathrm{pH}$, temperature, and kinetic parameters}

The optimum $\mathrm{pH}$, temperature, Michaelis-Menten constant $\left(K_{\mathrm{m}}\right)$, and the maximum initial velocity $\left(V_{\max }\right)$ were determined by changing each of the parameters and keeping all the other conditions constant. The activities of the native and modified enzymes were studied at $25^{\circ} \mathrm{C}$ at $\mathrm{pH} 3.0-5.5$ using $0.1 \mathrm{~mol} / \mathrm{L}$ acetate buffer and $6.0-8.0$ using $0.10 \mathrm{~mol} / \mathrm{L}$ phosphate buffer. The activities of the native and modified enzyme were studied at $40-80{ }^{\circ} \mathrm{C}$ and their optimum $\mathrm{pHs}$, respectively. Kinetic studies were carried out by changing the substrate concentration from 0.10 to $1.00 \mathrm{mmol} / \mathrm{L}$ and the initial velocity of catalysis $\left(v_{\mathrm{i}}\right)$ was measured by recording the absorbance increase $(\triangle A)$ at $10 \mathrm{~s}$ intervals over $1 \mathrm{~min}$ and plotting a straight line of $\Delta A$ versus $t$. The $K_{\mathrm{m}}$ and $V_{\max }$ values were obtained by a Hanes-Woolf (Eq. 2) plot and the turnover number $\left(k_{\mathrm{cat}}\right)$ was calculated according to Eq. 3.

$$
\begin{gathered}
{[\mathrm{S}] / v=1 / V_{\mathrm{m}} \times[\mathrm{S}]+K_{\mathrm{m}} / V_{\mathrm{m}}} \\
k_{\text {cat }}=V_{\mathrm{m}} /\left[E_{0}\right]
\end{gathered}
$$

The $\mathrm{pH}$ stability profile at $25^{\circ} \mathrm{C}$ was studied by incubating the enzyme in a $\mathrm{pH}$ range of 3.0-5.5 using $0.10 \mathrm{~mol} / \mathrm{L}$ acetate buffer and $6.0-8.0$ using $0.10 \mathrm{~mol} / \mathrm{L}$ phosphate buffer over $1 \mathrm{~h}$ and then assaying the residual enzyme activity at the optimum $\mathrm{pH}$. The activity of the native laccase at $\mathrm{pH} 4.5$ was taken as $100 \%$.

The thermal stability profile at the optimum $\mathrm{pH}$ was studied by incubating the enzyme at $20-60{ }^{\circ} \mathrm{C}$ over $1 \mathrm{~h}$ and then assaying the residual enzyme activity. The activity of the native laccase without thermal incubation was taken as $100 \%$.

\subsection{Removal efficiency of phenolics}

The phenolics $(o-, m-, p$-DHB) were dissolved in 0.10 $\mathrm{mol} / \mathrm{L}$ acetate buffer at $\mathrm{pH} 4.5$ and 5.5 to prepare the 4.0 $\mathrm{mmol} / \mathrm{L}$ phenolics solutions. The $5.0 \mathrm{ml}$ of $0.10 \mu \mathrm{mol} / \mathrm{L}$ native or modified laccase was added to $25 \mathrm{ml}$ of the pheno- 
lics solutions to react in the dark. Aliquots were withdrawn at 10 min intervals and the absorbance was determined at the maximum absorption wavelength of the corresponding phenolics. Acetate buffer was used as a reference. The phenolics removal efficiency (RE) was calculated using the following equation:

$$
\mathrm{RE}=\left(A_{0}-A\right) / A_{0} \times 100 \%
$$

where $A_{0}$ is the initial absorbance of the phenolics and $A$ is the absorbance of the phenolics after treatment by the native or modified laccase.

\section{Results and discussion}

\subsection{Purification, chemical modification, and characterization}

The crude laccase was fractionated at $45 \%-80 \%$ saturated ammonium sulfate precipitation. The recovery yield of the laccase activity was $87 \%$ and the specific activity of the purified laccase was $33 \mathrm{U} / \mathrm{mg}$. SA was used for the chemical modification of the purified laccase, which specifically reacted with the $\varepsilon$-amino groups of the laccase protein. The average amino modification yield of the SA-modified laccase was $85 \%$. Myceliophthora thermophila laccase has eight lysine residues [14] and approximately seven lysine residues were modified in the SA-modified laccase. SDS-PAGE electropherograms of the protein samples are shown in Fig. 1(a). Both the native laccase and the modified laccase were found to be homogeneous. Because the modifier SA is a small molecular substance, the difference between the native laccase and the modified laccase is not significant. Figure 1(b) shows that the molecular weight of the native laccase is $85.0 \mathrm{kD}$. The molecular weight of the native laccase was found to be identical to the reported value [23].
Proteins have ultraviolet absorption because they contain an aromatic and a heterocyclic conjugated system. The microenvironments of these conjugated rings (chromophores) determine the conformation of the protein. With regard to the position, strength, and shape of the absorption peaks the ultraviolet absorption spectra of these chromophores change with the conformation of the protein [24]. Differences in the $\mathrm{UV}-\mathrm{V}$ is spectra of the native laccase and the modified laccase are shown in Fig. 2(a). Compared with the native laccase the modified laccase shows a slight blue shift in its ultraviolet peak from 266-269 $\mathrm{nm}$ and its absorbance is $26 \%$ less. Nearly no absorbance difference or wavelength shift is observed for the $238 \mathrm{~nm}$ peak. It is known that changes in the ultraviolet spectrum of proteins in the 230-240 $\mathrm{nm}$ region are related to the transformation of the $\alpha$-helical while the absorbance decrease and the red shift of the peak in that region indicates a decrease in the $\alpha$ helix $[25,26]$. These results mean that the SA modification causes microenvironmental changes in the amino residues with aromatic and heterocyclic groups but few alterations in the $\alpha$-helical conformation of the protein.

Tryptophan and tyrosine residues are the major fluorescence groups and the microenvironments of these groups can affect the fluorescence intensity and peak position obviously [27]. From Fig. 2(b), a pronounced difference in the fluorescence spectra between the native and the modified laccases is evident. The modified laccase shows a shift in the maximum fluorescence emission peak from 369 to 382 $\mathrm{nm}$ and it shows a $10 \%$ increase in fluorescence intensity.

Similar changes in the enzyme's ultraviolet and fluorescence spectra are caused by chemical modification with acid anhydride, and this has also been observed in our previous work $[16,17]$. These changes further verify that laccase is modified with SA. After the chemical modification, the conformation of the enzyme was altered to a certain degree,

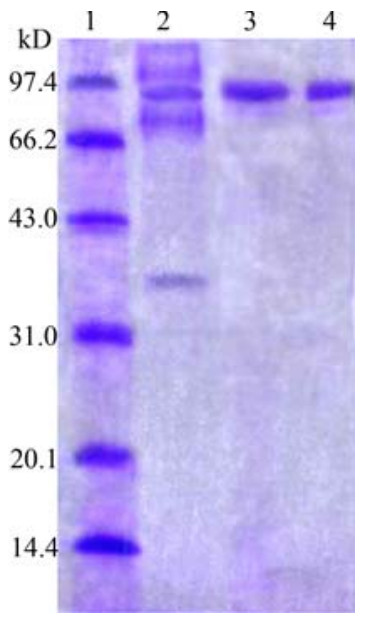

(a)

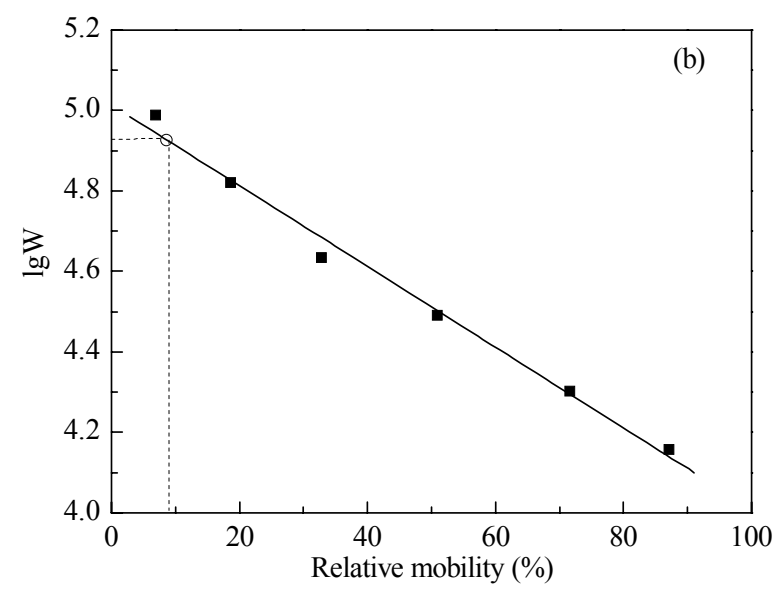

Fig. 1. SDS-PAGE electrophoresis (a) and estimation of the molecular weight (b) of the native and the modified laccases. Lane 1, protein molecular weight standards; lane 2, the crude laccase; lane 3, the native laccase; lane 4, the modified laccase. 

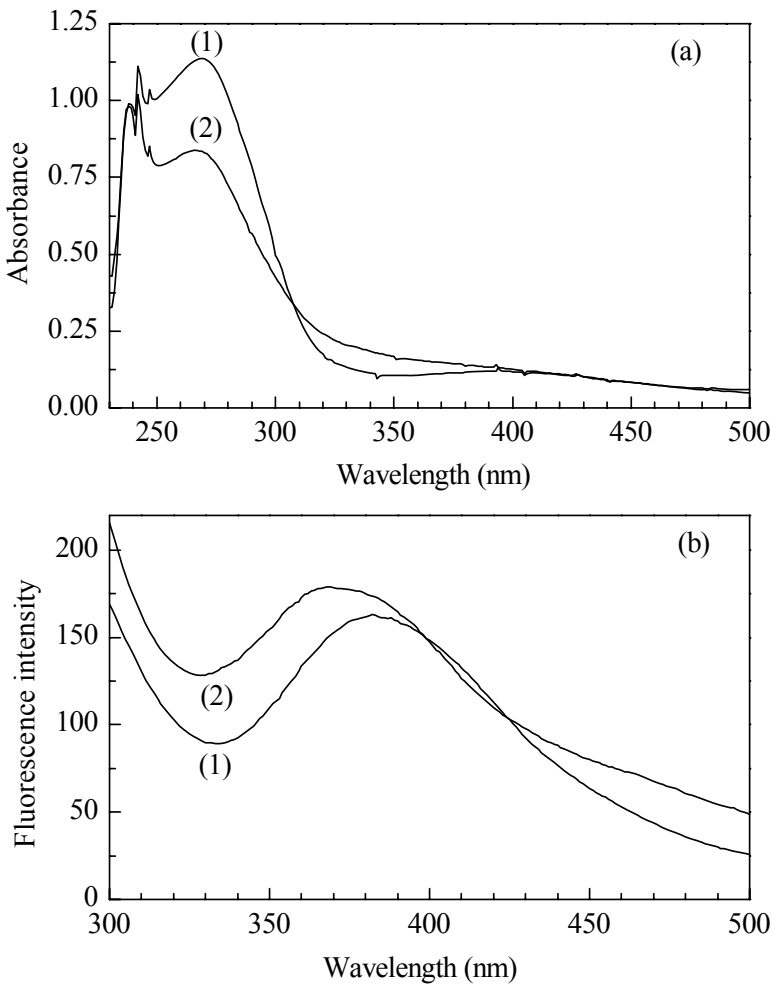

Fig. 2. UV-Vis (a) and fluorescence (b) spectra of the native (1) and the modified (2) laccases.

which caused the tryptophan and tyrosine residues to become more tightly enclosed and consequently the ultraviolet absorption decreased and the fluorescence intensity increased but the $\alpha$-helical conformation was not influenced.

\subsection{Effect of $\mathbf{p H}$}

The activities of the native and the modified laccases at different reaction pHs are shown in Fig. 3(a). The optimum $\mathrm{pH}$ of the native laccase was at 4.5 but for the modified laccase the optimum $\mathrm{pH}$ was 5.5. This is possible because of the reaction between the acid anhydride and the lysine residues of the laccase, which introduces carboxyl groups with an anionic charge into the enzyme molecule. This shifts the optimum $\mathrm{pH}$ to less acidic values [28]. The chemical modification of papain with anhydrides gave similar results $[17,28]$. An increase in the optimum $\mathrm{pH}$ of the laccase will be beneficial for its application. Compared with the native laccase in terms of its enzymatic activities in Fig. 3(a), the modified laccase has higher activity and its maximum activity is $60 \%$ higher. It has been reported that the modification of Myceliophthora thermophila laccase with CA and the modification of Trametes hirsuta laccase with glutaraldehyde leads to a three-fold increase and a 1.2-fold increase in enzymatic activity, respectively [14].

The native and modified laccases were incubated for $1 \mathrm{~h}$

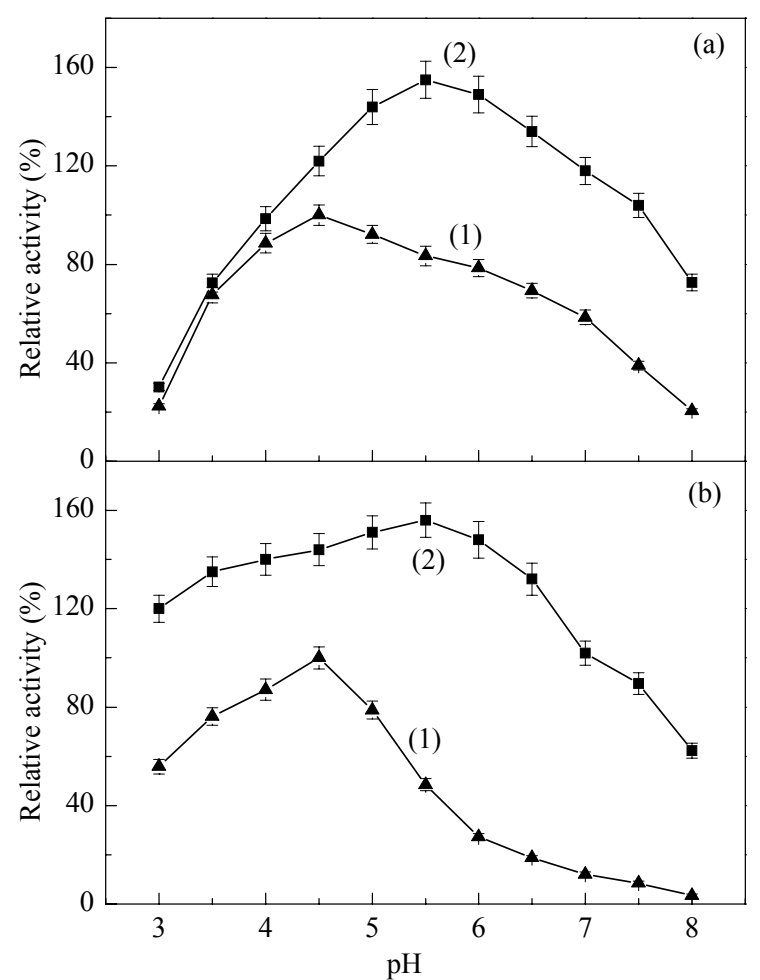

Fig. 3. Effects of reaction $\mathrm{pH}$ (a) and incubation $\mathrm{pH}(\mathrm{b})$ on the enzymatic activities of the native (1) and modified (2) laccases.

at $25^{\circ} \mathrm{C}$ at different $\mathrm{pHs}$ and their activities were measured and are shown in Fig. 3(b). The native laccase was the most stable at $\mathrm{pH}=4.5$ and it lost a significant amount of activity when the $\mathrm{pH}$ deviated from 4.5 , and it lost almost half its activity at $\mathrm{pH}=5.5$. However, the modified laccase exhibited much higher activity within a $\mathrm{pH}$ range of 2.5-7.0 and almost lost half its activity at $\mathrm{pH}=8.0$. These results indicate that the modified laccase has a higher $\mathrm{pH}$ stability than the native laccase.

An increase in the catalytic activity and $\mathrm{pH}$ stability of the enzyme is related to a change in its conformation. To determine the relationship between the enzymatic property and the conformation of laccase the ultraviolet (Fig. 4) and fluorescence (Fig. 5) spectra of the native and modified laccases at different $\mathrm{pHs}$ were determined. At about $270 \mathrm{~nm}$, as shown in Fig. 4, the conformations of the native and modified laccases change with a change in the environmental $\mathrm{pH}$ from their optimum $\mathrm{pH}$ but the absorption peak does not shift. When viewed in terms of the peak related to the $\alpha$ helix in Fig. 4, the native laccase shifts from 238 to $243 \mathrm{~nm}$ and the absorbance decreases from 0.987 to 0.520 with a change in $\mathrm{pH}$ from 4.5 to 1.0 . However, the peak of the modified laccase shifts from 238 to $240 \mathrm{~nm}$ and the absorbance decreases from 0.981 to 0.625 with a change in $\mathrm{pH}$ from 5.5 to 1.0. Obviously, the amplitude of variation in the ultraviolet absorption and the red shift of the peak related to 


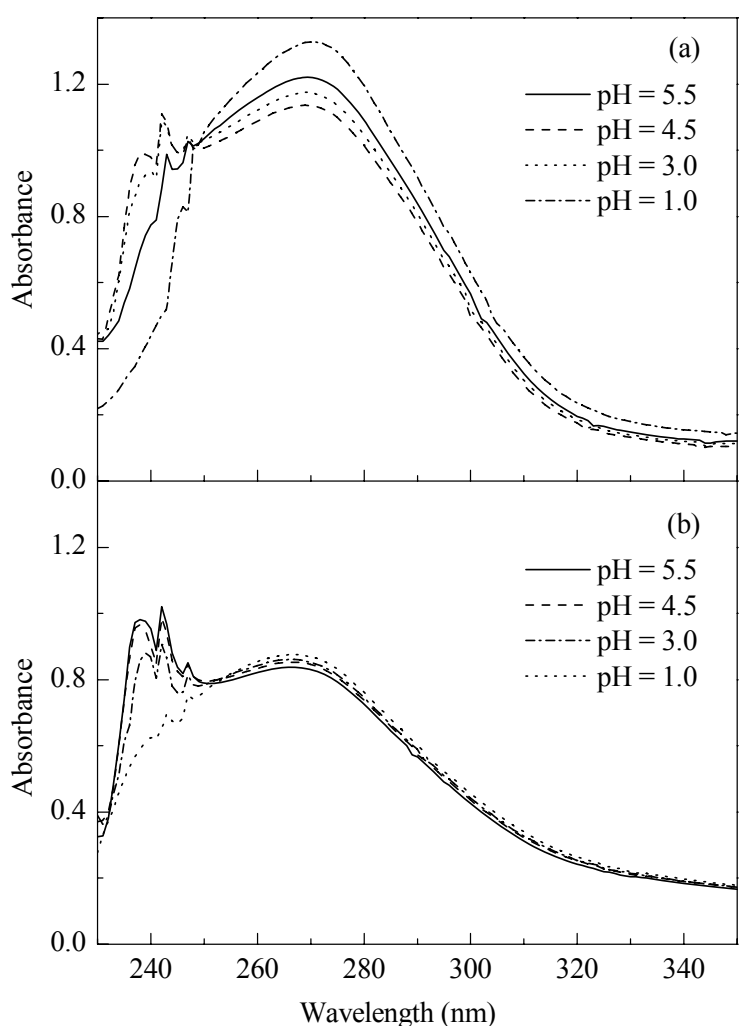

Fig. 4. UV-Vis spectra of the native (a) and modified (b) laccases at different $\mathrm{pHs}$.

the $\alpha$ helix of the modified laccase is smaller than that of the native laccase. This indicates that the conformation of the modified laccase under acidic conditions is more stable than that of the native laccase. Figure 5 also shows a similar feature but the fluorescence intensity increases and the maximum fluorescence emission peak shifts slightly to a longer wavelength. These spectra reveal that chemical modification with SA increases the $\mathrm{pH}$ stability of the laccase.

\subsection{Effect of temperature}

The activities of the native and modified laccases were examined at different temperatures for catalysis. Figure 6(a) shows that the optimum temperature of the modified laccase was $65^{\circ} \mathrm{C}$, which is the same as that of the native laccase and the activity of the modified laccase was always higher than that of the native laccase at the same temperature. When the temperature was above $65{ }^{\circ} \mathrm{C}$ the modified laccase lost its activity more slowly compared with the native laccase.

The native and modified laccases were incubated for $1 \mathrm{~h}$ at different temperatures and then their activities were measured (Fig. 6(b)). Both the laccases lost their activities with an increase in incubation temperature but the degree of decrease for the modified laccase was lower than that of the

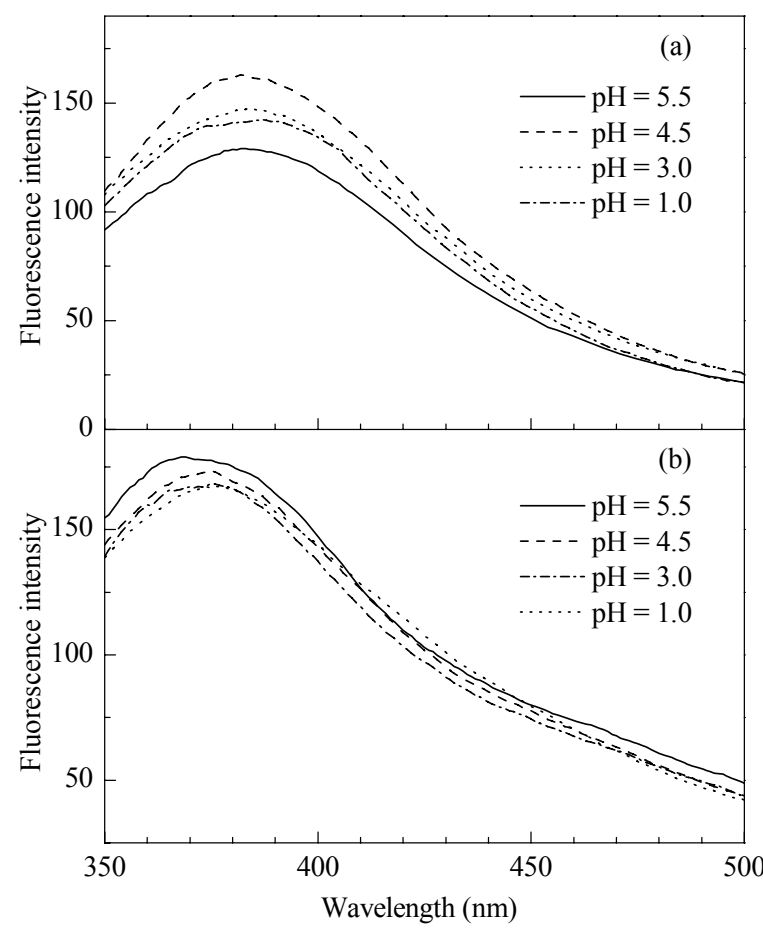

Fig. 5. Fluorescence spectra of the native (a) and modified (b) laccases at different $\mathrm{pHs}$.

native laccase. After treatment for $1 \mathrm{~h}$ at $65{ }^{\circ} \mathrm{C}$ the activities of the native and modified laccases were reduced by $80 \%$ and $41 \%$, respectively. Therefore, the modified laccase had a stronger thermal stability than the native laccase. Laccases from different origins were modified with different chemical modifiers and the difference in their thermal stabilities was large. Trametes hirsuta laccase showed a $7 \%$ and a $50 \%$ increase in thermal stability at $50{ }^{\circ} \mathrm{C}$ after modification with $2 \mathrm{kDa}$ and $5 \mathrm{kDa} \mathrm{PEG}$, respectively, and it gave a $50 \%$ decrease after modification with $1.1 \mathrm{kDa}$ [12]. Trametes $s p$. laccase that was modified with polyalkyleneoxide-co-maleic anhydride gave a 20 -fold and a 10 -fold increase in the thermal stability at $25{ }^{\circ} \mathrm{C}$ and $50{ }^{\circ} \mathrm{C}$, respectively [6]. Myceliophthora thermophila laccase modified with CA gave a 10 -fold increase in the thermal stability at $75^{\circ} \mathrm{C}$ [14].

\subsection{Kinetic studies}

Enzymatic activity is closely related to catalysis efficiency and the substrate affinity of enzymes. The kinetic parameters for the catalysis of the native and modified laccases were determined at their optimum $\mathrm{pH}$, respectively. A Hanes-Woolf plot (Fig. 7) showed a good linear relationship between $[S] / v$ and $[S]$. According to the slopes and intercepts of the native and modified laccases the corresponding kinetic parameters $K_{\mathrm{m}}, V_{\mathrm{m}}, k_{\text {cat }}$, and $k_{\text {cat }} / K_{\mathrm{m}}$ were 0.0954 $\mathrm{mmol} / \mathrm{L}, 5.34 \mu \mathrm{mol} /(\mathrm{L} \cdot \mathrm{min}), 50.9 \mathrm{~s}^{-1}$, and $534 \mathrm{~L} /(\mathrm{mmol} \cdot \mathrm{s})$ 

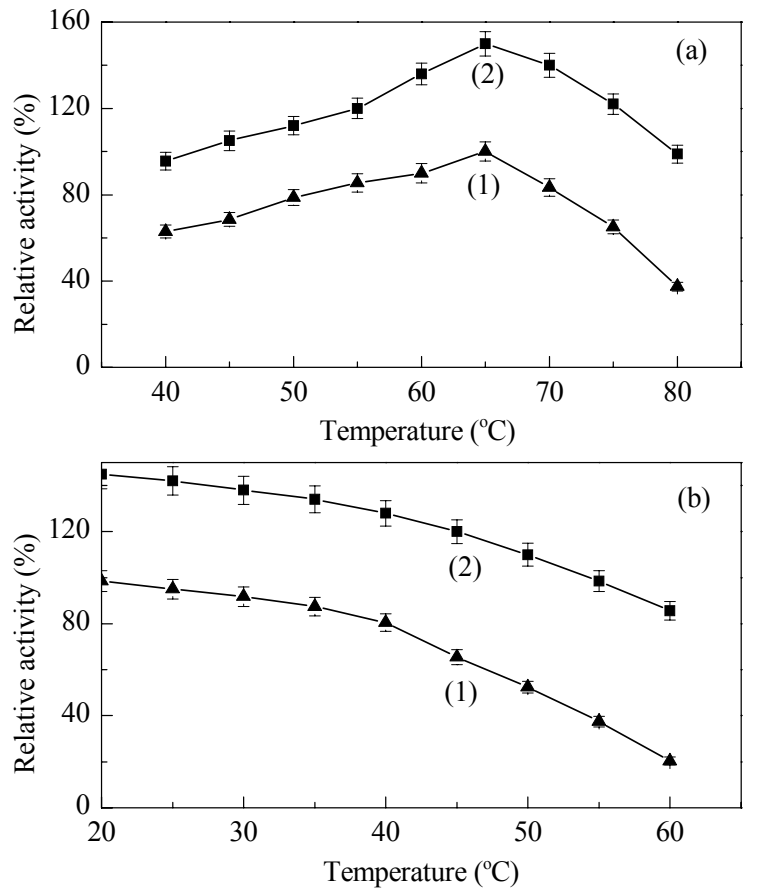

Fig. 6. Effects of reaction temperature (a) and incubation temperature (b) on the enzymatic activities of the native (1) and modified (2) laccases.

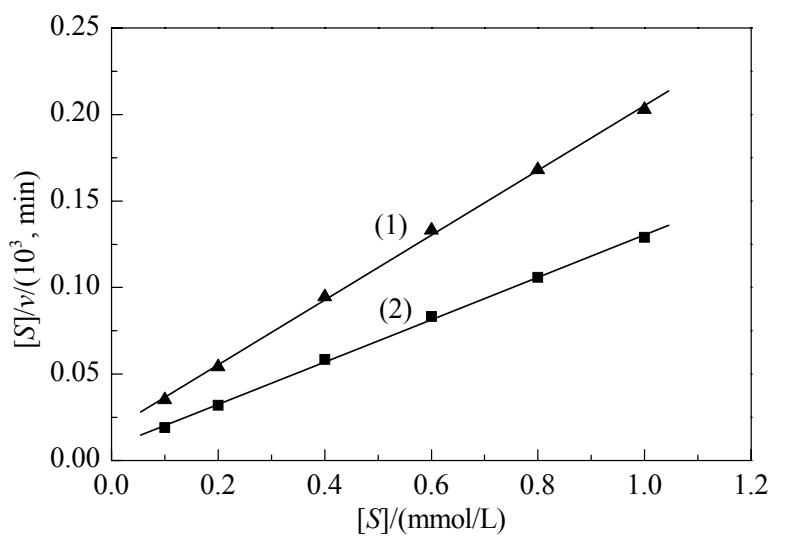

Fig. 7. Hanes-Woolf plots of the native and modified laccases at 25 ${ }^{\circ} \mathrm{C}$. (1) Native laccase at $\mathrm{pH}=4.5$; (2) Modified laccase at $\mathrm{pH}=5.5$. $\left[E_{0}\right]=1.75 \times 10^{-9} \mathrm{~mol} / \mathrm{L}$.

for the native laccase and $0.0655 \mathrm{mmol} / \mathrm{L}, \quad 8.17$ $\mu \mathrm{mol} /(\mathrm{L} \cdot \mathrm{min}), 77.8 \mathrm{~s}^{-1}$, and $1188 \mathrm{~L} /(\mathrm{mmol} \cdot \mathrm{s})$ for the modified laccase, respectively. $k_{\text {cat }}$ represents the catalytic efficiency and a larger $k_{\text {cat }}$ indicates a higher catalytic efficiency. Therefore, the catalysis efficiency of the modified laccase increased by $53 \%$ compared with the native laccase. $k_{\text {cat }} / K_{\mathrm{m}}$ is normally used to express the substrate affinity of the enzyme and a larger $k_{\text {cat }} / K_{\mathrm{m}}$ value indicates a higher substrate affinity. The substrate affinity of the modified laccase increased by $122 \%$ compared with that of the native laccase. These kinetic parameters indicate that the improvement in the modified laccase was due to the increase in catalytic efficiency and substrate affinity. The effect of chemical modification on laccases has been reported previously. The $k_{\text {cat }}$ values of Trametes versicolor modified with dextran was found to decrease by $1.4 \%$ and its $k_{\text {cat }} / K_{\mathrm{m}}$ value was found to decrease by $5.5 \%$ [13]. The $k_{\text {cat }}$ values of Trametes versicolor modified with PEGs of different molecular mass were found to increase but its $k_{\text {cat }} / K_{\mathrm{m}}$ values were found to decrease obviously [12].

\subsection{Phenolics removal efficiency}

Phenolics are major hazardous pollutants in water environments and they are harmful to human health. For example, $o$-DHB has a remarkable inhibitory effect on the central nervous system and it affects the DNA synthesis of leukocytes, which then leads to a chromosomal aberration. The treatment of phenolic wastewater with laccases is promising. In our experiments, the characteristic peaks of $o-, m-$, $p$-DHB, and their oxidation products that were catalyzed by laccase were determined by UV-Vis spectroscopy. They were at 279, 275, and $288 \mathrm{~nm}$ respectively for $o-, m-$, $p$-DHB and at 468, 477, and $508 \mathrm{~nm}$ for the corresponding oxidation products. Because of the difference in the ultraviolet peaks of the phenolics their corresponding oxidation products had large differences as well. The absorbances at the corresponding phenolic ultraviolet peaks were used to represent the phenolics concentration in the catalytic system. The $o-, m-, p$ - DHB solutions were treated with native and modified laccases and the phenolics removal efficiencies were determined at 10 min intervals (Fig. 8). Both the native and the modified laccase gave the highest removal efficiency for $p$-DHB and the lowest removal efficiency for

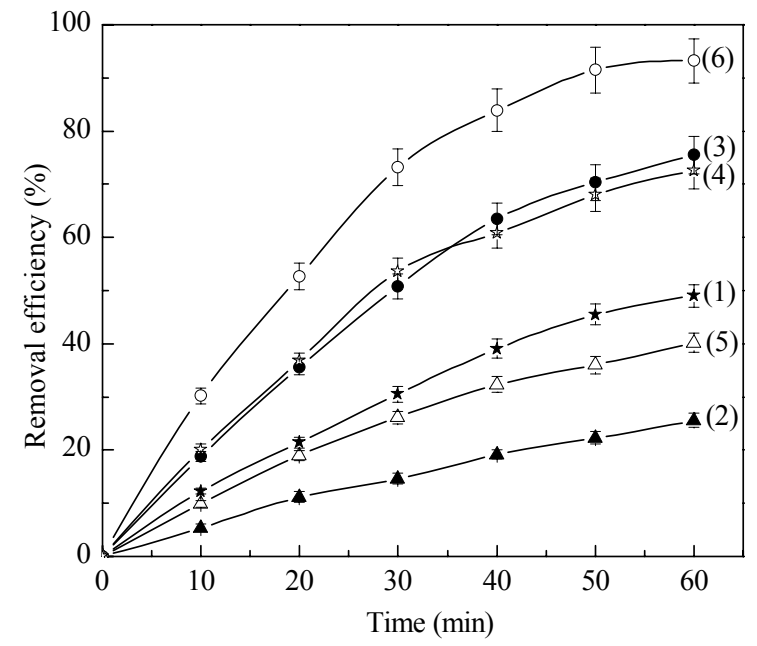

Fig. 8. Effect of reaction time on the removal efficiency of phenolics from aqueous solutions by the native laccase for $o$-DHB (1), $m$-DHB (2), and $p$-DHB (3) and the modified laccases for $o$-DHB (4), $m$-DHB (5), and $p$-DHB (6). 
$m$-DHB. The modified laccase exhibited a remarkably improved efficiency for all the phenolics compared with the native laccase. For example, the removal efficiencies for $o$-, $m$-, $p$-DHB at $1 \mathrm{~h}$ were $72.5 \%, 40.2 \%$, and $93.2 \%$, respectively, and these values are $48 \%, 57 \%$, and $18 \%$ higher compared with the native laccase, respectively. Shin-ya et al. [6] reported that the chemical modification of Trametes $s p$ laccase with polyalkyleneoxide-co-maleic anhydride improved the removal efficiencies of phenolics including mono-, di-, and tri-chlorophenols, cresol, and xylenol by $14 \%-231 \%$.

\section{Conclusions}

The chemical modification of amino groups in an enzyme with acid anhydrides is a simple and effective method and may provide a very valuable strategy to modify enzymes with new and useful characteristics related to their stability and catalytic effect. In this paper, a modified laccase with useful properties was obtained by the modification of laccase with SA. These properties include better combination with the substrate, higher activity, stronger $\mathrm{pH}$, thermal stability and a higher phenolics removal efficiency. These good effects are beneficial for the application of laccase in industries such as papermaking, printing and dyeing, and phenolic wastewater treatment etc. We speculate that seven lysine residues in the protein molecule are modified by SA. However, it is not known which lysine residues react with SA. Another point of interest is how the higher conformation of the protein changed with the degree of modification. This work will be carried out in the future because it will help us further understand what the effect of SA modification is on protein conformation and enzymatic properties.

\section{References}

1 Mayer A M, Staples R C. Phytochemistry, 2002, 60: 551

2 Baldrian P. FEMS Microbiol Rev, 2006, 30: 215

3 Piontek K, Antorini M, Choinowski T. J Biol Chem, 2002, 277: 37663

4 Thurston F. Microbiology, 1994, 140: 19

5 李阳, 蒋国翔, 牛军峰, 王颖, 呼丽娟. 化学进展 (Li Y, Jiang G X, Niu J F, Wang Y, Hu L J. Prog Chem), 2009, 21 :
2028

6 Shin-ya Y, Aye H N, Hong K J, Kajiuchi T. Enzyme Microb Technol, 2005, 36: 147

7 Tann C M, Qi D F, Distefano M D. Curr Opin Chem Biol, 2001, 5: 696

8 Iyer P V, Ananthanarayan L. Process Biochem, 2008, 43: 1019

9 刘建忠, 宋海燕, 翁丽萍, 计亮年. 分子催化 (Liu J Z, Song H Y, Weng L P, Ji L N. J Mol Catal(China)), 2002, 16: 475

10 DeSantis G, Jones J B. Curr Opin Biotechnol, 1999, 10: 324

11 Vandertol-Vanier H A, Vazquez-Duhalt R, Tinoco R, Pickard M A. J Ind Microbiol Biotechnol, 2002, 25: 214

12 Schroeder M, Heumann S, Silva C J S M, Cavaco-Paulo A, Guebitz G M. Biotechnol Lett, 2006, 28: 741

13 李苏, 间明, 戈钧, 刘铮. 化工学报 (Li S, Yan M, Ge J, Liu Z. J Chem Industry Eng (China)), 2007, 58: 3046

14 Forde J, Tully E, Vakurov A, Gibson T D, Millner P, Ó'Fágáin C. Enzyme Microb Technol, 2010, 46: 430

15 Song H Y, Yao J H, Liu J Z, Zhou S J, Xiong Y H, Ji L N. Enzyme Microb Technol, 2005, 36: 605

16 熊亚红, 苏健鸿, 刘小平. 分子催化 (Xiong Y H, Su J H, Liu X P. J Mol Catal(China)), 2010, 24: 435

17 熊亚红, 吴巧儿, 苏健鸿. 分子催化 (Xiong Y H, Wu Q E, Su J H. J Mol Catal(China)), 2010, 24: 529

18 Bourbonnais R, Paice M G. Appl Microbiol Biotechnol, 1992, 36: 823

19 Laemmli U K. Nature, 1970, 227: 680

20 Lowry O H, Rosebrough N J, Farr A L, Randall R J. J Biol Chem, 1951, 92: 265

21 熊亚红, 高敬忠, 郑坚鹏. 化学研究与应用 (Xiong Y H, Gao J Z, Zheng J P. Chem Res Appl), 2011, 23, 985

22 Habeeb A F S A. Anal Biochem, 1966, 14: 328

23 Zofia Olempska-Beer. 61st JECFA-Chemical and Technical Assessment (CTA): Laccase from Myceliophthora Thermophila expressed in Aspergillus Oryzae. Geneva: FAO, 2004. 4

24 阎隆飞, 孙之荣. 蛋白质分子结构. 北京: 清华大学出版社 (Yan L F, Sun Z R. Molecular Structure of Protein, Bejing: Tsinghua University press), 1999. 155

25 Glazer A N, Smith E L. J Biol Chem, 1961, 236: 2942

26 张丽, 秦德志, 杨维春, 刘巧茹, 王莉. 分析测试学报 (Zhang L, Qin D Z, Yang W C, Liu Q R, Wang L. J Instrum Anal), 2010, 29: 721

27 陶慰孙, 李惟, 姜涌明. 蛋白质分子基础. 北京：人民教育 出版社 (Tao W S, Li W, Jiang Y M. Foundation of Protein Molecule. Beijing: People's Education Press), 1981. 254

28 Khaparde S S, Singhal R S. Biores Technol, 2001, 78: 1 